\title{
Evaluation of Retinoblastoma and Ki-67 Immunostaining as Diagnostic Markers of Benign and Malignant Parathyroid Disease
}

\author{
Filip Farnebo, M.D., Ph.D., ${ }^{1}$ Gert Auer, M.D., Ph.D., ${ }^{2}$ Lars-Ove Farnebo M.D., Ph.D., ${ }^{3}$ \\ Bin Tean Teh, M.D., Ph.D., ${ }^{1}$ Stephen Twigg, M.D., ${ }^{4}$ Ulla Aspenblad, B.Sc., ${ }^{2}$ Norman W. Thompson, M.D., ${ }^{5}$ \\ Lars Grimelius, M.D., Ph.D., ${ }^{2}$ Catharina Larsson, M.D., Ph.D., ${ }^{1}$ Kerstin Sandelin, M.D., Ph.D. ${ }^{3}$ \\ ${ }^{1}$ Department of Molecular Medicine, Endocrine Tumor Unit, CMM L8:01, Karolinska Hospital, SE-171 76 Stockholm, Sweden \\ ${ }^{2}$ Department of Clinical Pathology, Karolinska Hospital, SE-171 76 Stockholm, Sweden \\ ${ }^{3}$ Department of Surgery, Karolinska Hospital, SE-171 76 Stockholm, Sweden \\ ${ }^{4}$ Kolling Institute of Medical Research, Royal North Shore Hospital, Sydney, New South Wales 2065, Australia \\ ${ }^{5}$ Department of Surgery, University of Michigan Hospital, 1500 Medical Center Drive, TC 2920-D, Ann Arbor, Michigan 48109, USA
}

\begin{abstract}
Assessment of the malignant potential of parathyroid tumors in the absence of metastases can be difficult using morphologic criteria alone. In this study we have examined a total of 58 parathyroid tumors (31 benign, 15 malignant, and 12 equivocal) from 54 patients using immunohistochemistry with monoclonal antibodies directed against the retinoblastoma (RB) protein and the cell cycle-associated antigen Ki-67 to evaluate their role as diagnostic markers. RB protein immunoreactivity was not useful for distinguishing between benign and malignant parathyroid tumors. Analysis of the proliferation marker Ki-67 showed that there was a trend toward more intense staining in the malignant cases. The Ki-67 labeling index was highest in the parathyroid cancers (median 33) and lowest in the sporadic primary adenomas (median 2). An observation that might have clinical implications is that tumors from patients with familial hyperparathyroidism linked to chromosome 1q showed a high Ki-67 index, indicating strong proliferative activity (median 25). This correlates well with the clinical observation of tumors with malignant potential in this syndrome. Because of the considerable overlap between groups of tumors, Ki-67 is not suitable for definitive differentiation between benign and malignant tumors. However, Ki-67 may give valuable information about which patients should be followed more closely.
\end{abstract}

Parathyroid tumorigenesis is a complex process in which various genetic abnormalities have been implicated [1-3]. Malignant transformation of parathyroid tumors is a rare phenomenon, and the incidence of parathyroid carcinoma in patients with primary hyperparathyroidism (PHPT) is less than 1\% [4]. Familial HPT is associated with a number of disorders, such as multiple endocrine neoplasia type I and II (MEN-I and MEN-II), neurofibromatosis type 1 (NF1), and the hyperparathyroidism jaw tumor syndrome (HPT-JT). Interestingly, parathyroid cancer seems to be associated with HPT-JT [5].

Clinically, patients with carcinoma present with symptomatic hypercalcemia, osteolytic bone changes, and renal impairment more often than patients with benign forms of HPT [6, 7]. Parathyroid carcinoma recurs locally or metastasizes to regional lymph nodes, lungs, liver, and bone. Markedly elevated calcium levels, rather than

Correspondence to: F. Farnebo, M.D., Ph.D. local tumor invasion or distant metastases, are the causes of death in these patients [4, 7-10]. Because of the risk of recurrence patients should be followed closely and repetitious surgical interventions be performed when necessary and feasible. The optimal chance to achieve complete cure for parathyroid cancer is when the tumor is removed en bloc at the primary operation [11].

In the absence of invasion of adjacent organs or structures or metastases, the diagnosis of cancer cannot be definitely established based on histopathology [4]. Identification of molecular markers for parathyroid malignancy would be of great importance in the clinical management of these patients. A recent study has proposed that loss of protein expression as well as somatic deletions of the retinoblastoma $(R B)$ gene is diagnostic for parathyroid carcinoma [12]. Deletions of the $R B$ gene also occur in atypical recurrent parathyroid disease [13]. These findings would give the $R B$ gene a possible diagnostic and prognostic role in the management of parathyroid tumors [12]. However, later studies on parathyroid tumors using RB immunohistochemistry have not been able to corroborate the findings of Cryns et al. [14, 15].

Immunohistochemistry for measurement of proliferative activity and thus assessment of the biologic behavior of tumors is widely used. The most reliable proliferation marker known so far is the cell cycle-associated Ki-67 antigen [16]. The proliferation index measured with Ki-67 in parathyroid tumors has been shown to be helpful for classifying these tumors $[14,17]$. In this study we have examined 58 parathyroid tumors using immunohistochemistry with monoclonal antibodies directed against the RB and Ki-67 nuclear proteins to evaluate their role as diagnostic markers in benign and malignant parathyroid tumors.

\section{Materials and Methods}

Tumor Material and Histopathology

A total of 58 tumors ( 31 benign, 15 malignant, 12 equivocal) from 54 patients with HPT were examined. The malignant and equiv- 
ocal cases were collected worldwide (see Acknowledgments), and the histopathology and clinical course of these cases were previously published [18]. Fifteen patients were diagnosed as having unequivocal parathyroid cancer and had either a microscopically infiltrative growth pattern, evidence of recurrence, or both. These tumors also often showed other pathologic features that occur in parathyroid cancer, such as marked fibrosis often with hyaline bands splitting the parenchyma and focally spread necrosis as well as cytologic features such as marked cellular atypia, macronucleoli, and large nuclei. The DNA distribution pattern was significantly abnormal compared to the so-called equivocal cases previously reported [18].

Twelve patients had tumors that exhibited histopathologic features of cancer, as described above, but lacked a microscopic infiltrative growth pattern or evidence of recurrence (i.e., equivocal cases). Mitotic figures were also less frequent in these equivocal tumors than in the cancers [18].

For comparison, 31 benign tumors of different genetic background were selected. These tumors originated from eight patients with sporadic HPT (eight glands), three patients with secondary HPT (seven glands), seven patients with familial MEN-I (seven glands), five patients from two families with HPT linked to the HRPT2 locus on chromosome 1q (five glands), two patients who had previously undergone radiation treatment to the neck (two glands), and two patients with familial hypocalciuric hypercalcemia (FHH) (two glands).

\section{$R B$ and Ki-67 Immunostaining}

Serial sections from representative formalin-fixed, paraffin-embedded blocks of tumors were screened for expression of RB and Ki-67. The RB monoclonal antibody PMG3-245 (PharMingen, San Diego, CA, USA) specifically targets the epitope from amino acid 300 to 380 of the pRB protein and recognizes phosphorylated as well as nonphosphorylated protein. The MIB-1 monoclonal antibody (Immunotech, Marseille, France) recognizes a determinant of the Ki-67 antigen. A 1:200 dilution of the RB and a 1:150 dilution of the MIB-1 antibodies were used. Deparaffinized sections $4 \mu \mathrm{m}$ thick were rehydrated, and endogenous peroxidase activity was suppressed with $0.5 \% \mathrm{H}_{2} \mathrm{O}_{2}$ for 30 minutes. The sections were then heated in citrate buffer $(\mathrm{pH} \mathrm{6.0)}$ for $2 \times 5$ minutes at $750 \mathrm{~W}$ in a household microwave oven to intensify the immunohistochemical result [19]. Primary antiserum was added overnight at $4^{\circ}$ to $8^{\circ} \mathrm{C}$, and the site of antigen-antibody binding was visualized according to the avidin-biotin-peroxidase complex method (ABC Elite, Vector Laboratories, Burlingame, CA, USA), following the manufacturer's instructions. Diaminobenzidine (DAB) was used as chromogen, and the sections were counterstained with Mayers hematoxylin. A positive control (lymph node metastasis of breast cancer) was included in each experiment.

All sections were scored by at least two independent investigators. The RB nuclear immunostaining was scored according to the following criteria: 0 , absent; + , weak; ++ , moderate; +++ , strong staining (Fig. 1). Ki-67 positivity was quantified by counting a total of 1000 cells from multiple areas of the slide in a randomized fashion. The results are given as the median and range. Differences between groups was tested using the MannWhitney U-test (two unpaired groups) or the Kruskal-Wallis test (more than two groups).

\section{Results}

The results of the staining for RB are summarized in Table 1 and exemplified in Figure 1. The tumors displayed a wide range of staining intensity, with no diagnostic specific pattern seen in any of the subgroups. Figures $1 \mathrm{c}$ and $1 \mathrm{~d}$ show RB and Ki-67 staining of a tumor from a 52-year-old male patient where the initial diagnosis was consistent with a parathyroid adenoma. However, soon after the operation the patient became hypercalcemic and underwent two cervical explorations for recurrent disease. At this time the tumors fulfilled all criteria of parathyroid cancer. The immunohistochemical analysis was performed on tumor tissue from the time of reexploration. The tumor was scored as $\mathrm{RB}++$ and had a Ki-67 index of 133. This patient died from unremitting disease after a period of 30 months.

The scoring of the Ki-67 staining is shown in Figure 2 and exemplified in Figure 1. The median Ki-67 indexes for cancer, equivocal cases, sporadic adenomas, secondary HPT, MEN-I and familial HPT were $33,14,2,6,7$, and 25 , respectively. There is a statistically significant difference between these groups $(p=0.04)$. The difference between the cancer groups and the sporadic adenomas is highly significant ( $p=0.007)$.

The five tumors from patients with familial PHPT linked to the HRPT2 locus on chromosome $1 \mathrm{q}$ were histopathologically diagnosed as benign lesions. Ki-67 staining of a parathyroid tumor from a patient with familial HPT-JT syndrome is shown in Figure 1f. The patient is a 35-year-old man who was operated on at age 26 (1989) for a fast-growing tumor in the left maxilla. During hospitalization PHPT was diagnosed, and at neck exploration a 2.35-g abnormal parathyroid gland was removed. Since the parathyroidectomy the patient has remained normocalcemic but has developed another large maxillary tumor that has also been removed [20]. The Ki-67 indexes of the two tumors from patients who had previously undergone radiation therapy were 2 and 36. The two parathyroid glands from patients with $\mathrm{FHH}$ had indexes of 19 and 16.

The relation between $\mathrm{RB}$ staining and $\mathrm{Ki}-67$ index is presented in Figure 3. Tumors lacking RB staining also had the lowest Ki-67 index.

\section{Discussion}

The $R B$ gene is a tumor-suppressor gene with a growth-inhibitory effect in the cell cycle. It has been implicated in the pathogenesis of a number of human cancers $[21,22]$. Our study shows that RB immunohistochemical staining cannot be used to distinguish between benign and malignant parathyroid tumors. The results markedly contrast with those of Cryns et al. [12] but are in agreement with the study performed by Lloyd et al. [14]. A possible explanation for the discrepancy is that the former authors used a polyclonal antibody, whereas in the latter study and in the present study monoclonal antibodies were used. How the slides are stored prior to the immunostaining may also affect the results [23].

In some parathyroid carcinomas and adenomas RB was strongly positively stained, whereas in others it was not stained. It is not known what causes the low RB protein expression. One possible explanation is less stable mRNA or transcriptional regulation. Another explanation would be loss of one of the alleles at the RB locus on chromosome 13q14. Such losses have been 

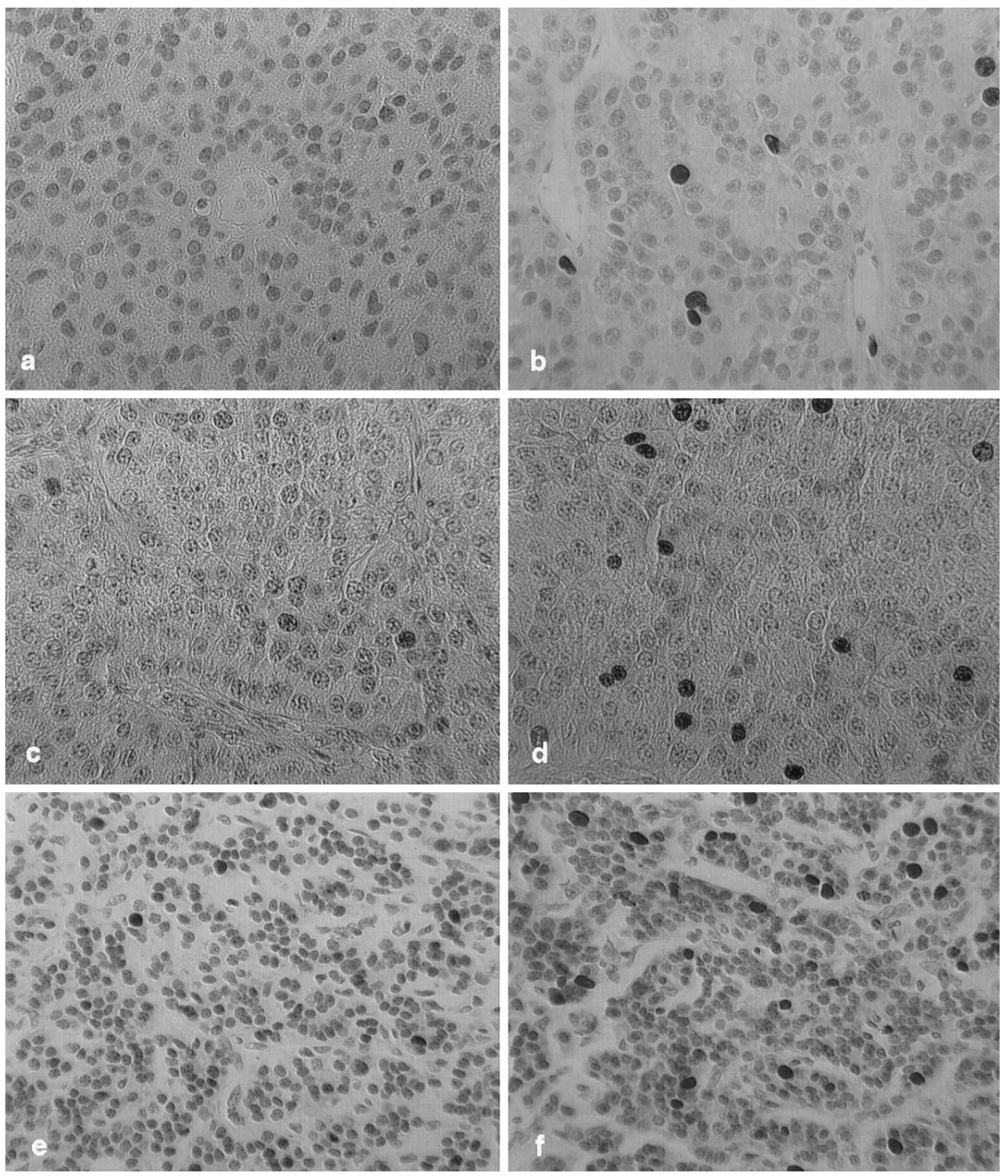

Fig. 1. Microphotographs of parathyroid tumors stained for RB (left) and Ki-67 (right). a, b. Tumor from a patient with HPT-JT syndrome (RB staining,$+ \mathrm{Ki}-67$ index 36). c, d. Patient with parathyroid cancer (RB staining ,++ Ki-67 index 133). e, f. Patient with parathyroid cancer (RB staining +++ , Ki-67 index 90). demonstrated in both benign and malignant parathyroid tumors $[12,13]$. Additional studies of loss of heterozygosity (LOH) for markers in the $R B$ gene in this laboratory showed that some carcinomas retain both alleles (data not shown), whereas $\mathrm{LOH}$ could be demonstrated in some benign tumors [2].

This study indicates that the proliferation marker Ki-67 may be of greater value for discriminating between benign and malignant tumors. However, the precise role of $\mathrm{Ki}-67$ is not immediately evident, as there is a considerable overlap between various tumors.

Previous studies on the proliferative activity of parathyroid glands using tritiated thymidine have shown that the labeling index in sporadic adenomas and in hyperplastic glands from patients with secondary HPT is extremely low, approximately 0.25 labeled cells/1000 [24, 25]. The 10-fold higher frequency seen in this study may be due to labeling of a greater fraction of the cell cycle by Ki-67 [26]. An even higher Ki-67 index in adenomas was reported by Abbona et al. (mean 32.8) [17] and Lloyd et al. (mean 24) [14]. A significant difference between clinically evident cancers and adenomas was demonstrated in both these studies. In the work by Lloyd et al. [14] there was a certain overlap between the malignant and benign tumors. Abbona et al. [17] reported only mean values and no standard deviation, which makes the degree of overlap difficult to evaluate. Wang et al. found a Ki-67 index of less than 10 in 13 of 21 adenomas. Two adenomas had an index exceeding 50 [27].

When the equivocal cases and unequivocal parathyroid cancers were compared no statistical difference could be demonstrated, although numerically the median value was lower among the equivocal cases. This is in accordance with the findings of Abbona et al. and Lloyd et al., who did not find any statistical difference between tumors from patients with an aggressive or an indolent clinical course. The same tendency could be seen in the present investigation. It is therefore possible that among the cases classi- 
Table 1. RB staining of parathyroid tumors.

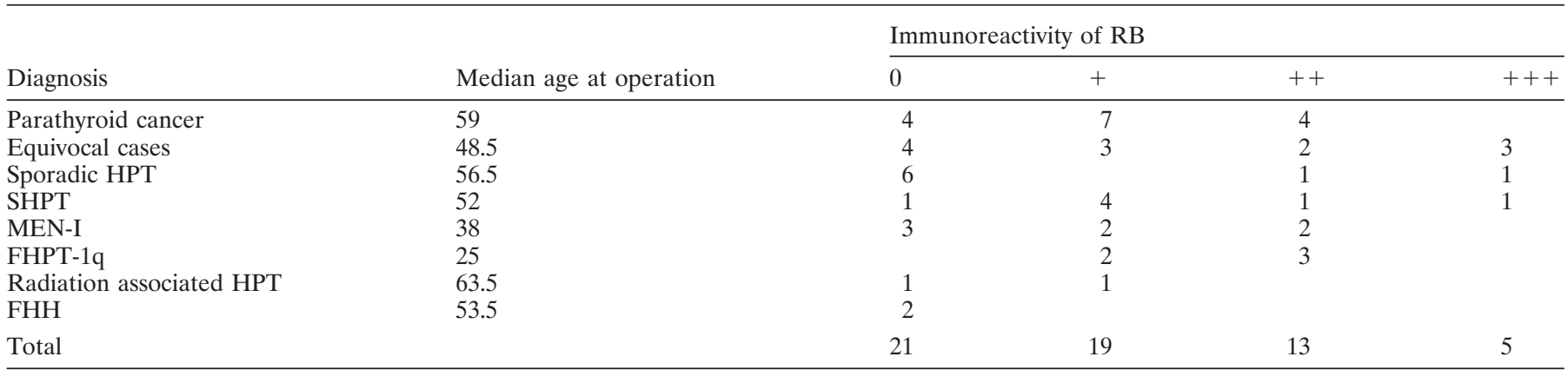

0 : absent; +: weak; ++: moderate; +++ : strong nuclear staining.

FHPT-1q: familial hyperparathyroidism linked to 1q; FHH: familial hypocalciuric hypercalcemia; MEN-I: multiple endocrine neoplasia type I; RB: retinoblastoma; SHPT: secondary hyperparathyroidism.

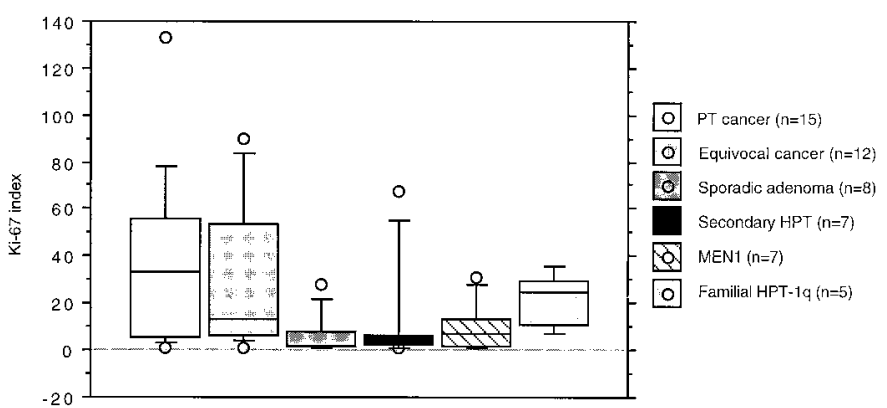

Fig. 2. Box plot of Ki-67 index for six groups of parathyroid (PT) tumors. Median and interquartile ranges are in the box; 10th and 90th percentiles are indicated by transverse bars; single values outside the 10th and 90th percentiles are shown by circles.

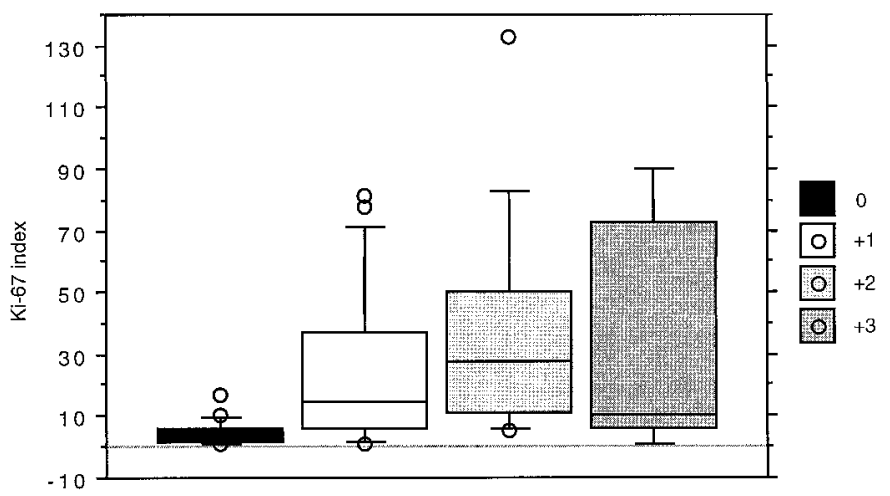

Fig. 3. Box plot of Ki-67 index for 57 parathyroid tumors grouped according to their immunoreactivity to RB protein. Median and interquartile ranges are in the box; 10th and 90th percentiles are indicated by transverse bars; single values outside 10th and 90th percentiles are shown by circles.

fied as "equivocal" some tumors in fact were benign. Further support for this statement is the mean disease-free follow-up of 12 years. The Ki-67 index of the MEN-I tumors was in the same range as that of the adenomas underlining the benign nature of these tumors.

An observation that might have clinical implications is that tumors from patients with familial HPT linked to chromosome 1q show intense staining for Ki-67, indicating strong proliferative activity. This correlates well with the clinical observation of more aggressive tumors with malignant potential in this syndrome. Parathyroid cancer has been reported to occur in 3 of the 12 described families linked to 1q [28-30]. However, none of the tumors analyzed in this study showed any histopathologic malignant features. Patients with HPT-JT can develop multiple adenomas, and one patient was operated on twice. The median follow-up of these patients is 8 years, with no sign of malignant transformation.

Dionisio et al. [31] reported a high Ki-67 index in one case of secondary HPT where a single parathyroid gland transplanted to the arm showed signs of excessive growth. Based on the high Ki-67 index the authors concluded that that gland must represent parathyroid cancer. In view of the overlap between different groups of parathyroid tumors seen in the present investigation, we would be hesitant to draw such definitive conclusions from a high Ki-67 index. Apparently, some tumors of secondary HPT, with no suspicion of cancer, have high proliferative activity and might not be suitable for grafting.

\section{Conclusions}

This study shows that RB cannot be used to distinguish between benign and malignant parathyroid tumors. Nor can the proliferation marker Ki-67 be used for safe differentiation between benign and malignant tumors in a single specific case. On the other hand, Ki-67 gives additional information that may be used to decide which patients must be followed more closely, especially those with familial HPT and in cases where the histopathology remains equivocal and clinical signs of malignancy are lacking.

\section{Résumé}

Evaluer le potentiel malin des tumeurs de la parathyrö̈de en l'absence de métastases peut être difficile en se basant uniquement sur des critères morphologiques. Dans cette étude nous avons examiné 58 tumeurs de la parathyroïde (31 tumeurs bénignes, 15 malignes et 12 équivoques) chez 54 patients par des tests immunochimiques utilisant des anticorps monoclonaux contre la protéine de rétinoblastome $(\mathrm{RB})$ et l'antigène cellulaire Ki-67 pour évaluer leur rôle potentiel de marqueur diagnostique. Du point de vue immunochimique, la protéine RB n'était pas très utile pour distinguer entre tumeur bénigne et maligne de la 
parathyroïde. L'analyse du marqueur de la prolifération Ki-67 a montré que la coloration était plus prononcée en cas de tumeur maligne. L'index d'étiquetage au marqueur Ki-67 était le plus élevé en cas de cancer de la parathyroïde (médiane 33) et le plus bas en cas d'adénome primitif sporadique (médiane 2). Un fait qui pourrait avoir un intérêt clinique est que les tumeurs des patients se présentant avec un hyperparathyrö̈disme familial lié au chromosome 1q avaient un indexe Ki-67 élevé indiquant une activité de prolifération importante (médiane 25). Ceci est en corrélation avec l'observation clinique des tumeurs ayant un potentiel malin dans ce syndrome. En raison de la faible spécificité entre les groupes, l'utilisation du marqueur Ki-67 n'est pas adaptée pour différencier entre les tumeurs bénignes et malignes. Le marqueur Ki-67, cependant, pourrait être utile comme indicateur des patients qui devraient être suivis de près.

\section{Resumen}

Basándose exclusivamente en criterios morfológicos, es difícil, si no existen metástasis, diagnosticar la posible malignización de los tumores paratiroideos. Por ello, en el presente estudio, hemos tratado de valorar, mediante técnicas immunohistoquímicas, el papel que pueden tener, como marcadores diagnósticos, los anticuerpos monoclonales directos contra la proteína del retinoblastoma (RB) y los antígenos, asociados al ciclo celular, Ki-67. Nuestra casuística comprende 54 pacientes, con 58 tumores paratiroideos: 31 benignos, 15 malignos y 12 de naturaleza incierta. La immunorreactividad de la proteína RB no fue útil para dilucidar la benígnidad o malígnidad de los tumores paratiroideos. El índice de proliferación de los antígenos Ki-67 fue alto, en los cánceres paratiroideos (media 33) y bajo, en los esporádicos adenomas primarios (media 2). Observamos un hecho que puedo tener importancia clínica; en tumores de pacientes con hiperparatiroidismo familiar ligado al cromosoma 1q, el índice Ki-67 (media 25) fue muy alto, lo que indica una gran actividad celular proliferativa. Este hecho guarda estrecha relación con el síndrome de hiperparatiroidismo familiar, en el que se observa una evidente predisposición a la malignización. El Ki-67 no es un test válido para el diagnóstico diferencial definitivo entre tumores malignos y benignos, debido al solapamiento de los valores detectados entre ambos grupos. Sin embargo, el Ki-67 proporciona una información útil para detectar, a aquellos pacientes que han de tener un seguimiento clínico más estricto, con objeto de diagnosticar precozmente una posible malignización tumoral.

\section{Acknowledgments}

This work was supported by the Hagberg Foundation, Swedish Medical Research Council, Swedish Cancer Foundation, Cancer Society of Stockholm, Magn. Bergvall Foundation, Gustav V Jubilee Fund, Martin Rind Foundation, Sigurd \& Elsa Goljes Foundation, and Fredrik and Ingrid Thuring Foundation. The authors are indebted to the following for contribution of clinical data and tissue specimens: L. Bergljung, M.D.; P. Cheung, M.D.; C. Dubost, M.D.; L. Engevik, M.D.; P.O. Granberg, M.D.; J.F. Henry, M.D.; S. Jansson, M.D.; P.H. Magnuson, M.D.; J. Nordenström, M.D.; C. Organ, M.D.; C. Proye, M.D.; J. Salomon, M.D.; E. Sarfati, M.D.; Ö. Selking, M.D.; D.M. Shapiro, M.D.; and J. Visset, M.D.

\section{References}

1. El-Deiry, S., Levine, M.A.: Molecular overtones of primary hyperparathyroidism. J. Clin. Endocrinol. Metab. 80:3105, 1995

2. Farnebo, F., Teh, B.T., Dotzenrath, C., Wassif, W.S., Svensson, A., White, I., Betz, R., Goretzki, P., Sandelin, K., Farnebo, L-O., Larsson, C.: Differential loss of heterozygosity in familial, sporadic, and uremic hyperparathyroidism. Hum. Genet. 99:342, 1997

3. Tahara, H., Smith, A.P., Gaz, R.D., Cryns, V.L., Arnold, A.: Genomic localization of novel candidate tumor suppressor gene loci in human parathyroid adenomas. Cancer Res. 56:599, 1996

4. Sandelin, K., Thompson, N.W., Bondeson, L.: Metastatic parathyroid carcinoma: dilemmas in management. Surgery 110:978, 1991

5. Jackson, C.E., Norum, R.A., Boyd, S.B., Talpos, G.B., Wilson, S.D., Taggart, T., Mallette, L.E.: Hereditary hyperparathyroidism and multiple ossifying jaw fibromas: a clinically and genetically distinct syndrome. Surgery 108:1006, 1990

6. Levin, K.E., Galante, M., Clark, O.H.: Parathyroid carcinoma versus parathyroid adenoma in patients with profound hypercalcemia. Surgery 101:649, 1987

7. Shane, E., Bilezikan, J.P.: Parathyroid carcinoma: a review of 62 patients. Endocr. Rev. 3:218, 1982

8. Anderson, B.J., Samaan, N.A., Vassilopopulou-Sellin, R., Ordonez, N.G., Hickey, R.C.: Parathyroid carcinoma: features and difficulties in diagnosis and management. Surgery 94:906, 1983

9. Vetto, J.T., Brennan, M.F., Woodruff, J., Burt, M.: Parathyroid carcinoma: diagnosis and clinical history. Surgery 114:882, 1993

10. Wynne, A.G., van Heerden, J., Carney, J.A., Fitzpatrick, L.A.: Parathyroid carcinoma: clinical and pathologic features in 43 patients. Medicine 71:197, 1992

11. Wang, C.A., Gaz, R.D.: Natural history of parathyroid carcinoma: diagnosis, treatment, and results. Am. J. Surg. 149:522, 1985

12. Cryns, V.L., Thor, A., Xu, H.J., Hu, S.X., Wierman, M.E., Vickery, A.L., Jr., Benedict, W.F., Arnold, A.: Loss of the retinoblastoma tumor-suppressor gene in parathyroid carcinoma. N. Engl. J. Med. 330:757, 1994

13. Dotzenrath, C., Teh, B.T., Farnebo, F., Cupisti, K., Svensson, A., Toll, A., Goretzki, P., Larsson, C.: Allelic loss of the retinoblastoma tumour suppressor gene: a marker for aggressive parathyroid tumours? J. Clin. Endocrinol. Metab. 81:3194, 1996

14. Lloyd, R.V., Carney, A.J., Ferreiro, J.A., Long, J., Thompson, G.B., van Heerden, J.A., Grant, C.S., Wollan, P.C.: Immunohistochemical analysis of the cell cycle-associated antigens Ki-67 and retinoblastoma protein in parathyroid carcinomas and adenomas. Endocr. Pathol. 4:279, 1995

15. Subramaniam, P., Wilkinson, S., Shepherd, J.J.: Inactivation of retinoblastoma gene in malignant parathyroid growths: a candidate genetic trigger? Aust. N.Z. J. Surg. 65:714, 1995

16. Fritz, P., Wu, X., Multhaupt, H., Schwarzmann, P.: Quantitation in immunohistochemistry: a research method or a diagnostic tool in surgical pathology? Pathologica 87:300, 1995

17. Abbona, G.C., Papotti, M., Gasparri, G., Bussolati, G.: Proliferative activity in parathyroid tumors as detected by Ki-67 immunohistostaining. Hum. Pathol. 26:1135, 1995

18. Bondesson, L., Sandelin, K., Grimelius, L.: Histopathological variables and DNA cytometry in parathyroid carcinoma. Am. J. Surg. Pathol. 17:820, 1993

19. Shi, S.R., Key, M.E., Kalra, K.L.: Antigen retrieval in formalin-fixed, paraffin-embedded tissue: an enhancement method for immunohistochemical staining based on microwave oven heating of tissue sections. J. Histochem. Cytochem. 39:741, 1991

20. Teh, B.T., Farnebo, F., Kristoffersson, U., Sundelin, B., Cardinal, J., Axelson, R., Yap, A., Epstein, M., Heath, H., III, Cameron, D., Larsson, C.: Autosomal dominant primary hyperparathyroidism-jaw tumor syndrome associated with adult nephroblastoma and cystic kidney disease: linkage to 1q21-q32 and loss of the wild-type allele in nephroblastomas. J. Clin. Endocrinol. Metab. 81:4204, 1996

21. Benedict, W.F., Xu, H.J., Hu, S.X., Takahashi, R.: Role of the retinoblastoma gene in the initiation and progression of human cancer. J. Clin. Invest. 85:988, 1990

22. Weinberg, R.A.: Tumor suppressor genes. Science 254:1138, 1991

23. Jacobs, T.W., Prioleau, J.E., Stillman, I.E., Schnitt, S.J.: Loss of tumor 
marker-immunostaining intensity on stored paraffin slides of breast cancer. J. Natl. Cancer Inst. 15:1054, 1996

24. Lloyd, H.M., Parfitt, A.M., Jacobi, J.M., Willgoss, D.A., Craswell, P.W., Petrie, J.J., Boyle, P.D.: The parathyroid glands in chronic renal failure: a study of their growth and other properties, based on findings in hypercalcemia patients. J. Lab. Clin. Med. 114:358, 1989

25. Parfitt, A., Willgoss, D., Jacobi, J., Lloyd, H.: Cell kinetics in parathyroid adenomas: evidence for decline in rates of cell birth and tumor growth, assuming clonal origin. Clin. Endocrinol. (Oxf.) 35:151, 1991

26. Quinn, C., Wright, N.: The clinical assessment of proliferation and growth in human tumours: evaluation of methods and applications as prognostic variables. J. Pathol. 160:93, 1990

27. Wang, W., Johansson, H., Kvasnicka, T., Farnebo, L-O., Grimelius, L.: Detection of apoptotic cells and expression of Ki-67 antigen, Bcl-2, p53 oncoproteins in human parathyroid adenoma. Acta Pathol. Microbiol. Immunol. Scand. 104:789, 1996

\section{Invited Commentary}

\author{
Ricardo V. Lloyd, M.D. \\ Division of General Surgery, Mayo Clinic, Rochester, Minnesota, USA
}

The diagnosis of parathyroid carcinoma can be difficult histopathologically in the absence of invasion of adjacent organs or structures, metastatic disease or both $[1,2]$. The presence of certain histologic features including cellular and nuclear pleomorphism and general tumor size have not been particularly useful for making this diagnosis. Mitotic counts may be helpful for evaluating the malignant potential of parathyroid tumors; but several variable such as tissue preservation can influence this analysis and, in many endocrine tumors, including those of the parathyroid, mitoses may be difficult to find. In recent years, various proliferation markers associated with the cell cycle that can be detected by immunohistochemistry in formalin-fixed paraffin-embedded tissue sections have been used for histopathologic studies [3]. Antibodies to Ki-67 and a cell cycle protein detected in all phases of the cell cycles except $\mathrm{G}_{0}[4,5]$ have been used in attempts to distinguish between low-grade and high-grade tumors as well as adenomas and carcinomas.

In this issue Farnebo et al. examined retinoblastoma (RB) and $\mathrm{Ki}-67$ expression as potential diagnostic markers of parathyroid tumors in a series of 58 tumors (31 benign, 15 malignant, 12 equivocal). RB protein immunoreactivity was not useful for distinguishing between benign and malignant parathyroid tumors. However, Ki-67 analysis showed that there was a trend toward a higher percentage of cells staining in the malignant cases, with a median Ki-67 labeling index of 33 in parathyroid carcinomas and of 2 in sporadic primary adenomas. Interestingly, patients with familial hyperparathyroidism also had a high Ki-67 labeling index, with a mean of 25 , which correlates with the clinical observation of tumors with malignant potential associated with this syndrome.
28. Dinnen, J.S., Greenwood, R.H., Jones, J.H., Walker, D.A., Williams, D.E.: Parathyroid carcinoma in familial hyperparathyroidism. J. Clin. Pathol. 30:966, 1977

29. Kakinuma, A., Morimoto, I., Nakano, Y., Fujimoto, R., Ishida, O., Okada, Y., Inokuchi, N., Fujihira, T., Eto, S.: Familial hyperparathyroidism complicated with Wilm's tumour. Intern. Med. 33:123, 1994

30. Pidwirny, G.N., Szabo, J., Hobbs, M., Heath, H., Jackson, C.E.: Follow-up of two hyperparathyroidism-jaw tumor syndrome families reported in 1971 and 1981 reveals that they are related and that parathyroid cancer is a part of the syndrome. Am. J. Hum. Gen. 57:A75, 1995

31. Dionisio, P., Stramignoni, E., Passarino, G., Pucci, A., Valenti, M., Berto, I.M., Portigliatti Barbos, M., Cadario, A., Gasparri, G., Bajardi, P.: Recurrent secondary hyperparathyroidism due to parathyroid carcinoma: usefulness of Ki-67 immunostaining in the diagnosis of a malignant parathyroid tumor. Nephron 74:720, 1996
The finding of differences in Ki-67 labeling indices between adenomas and carcinomas agrees with that of other recent reports $[6,7]$.

Can Ki-67 be used to distinguish between benign and malignant parathyroid tumors? The authors correctly conclude that it cannot because of the considerable overlap in Ki-67 indices in different groups of tumors. A confounding variable in this study is the large group of patients $(n=12)$ with a diagnosis of equivocal tumors. Unfortunately, follow-up information was not available to determine if these cases were truly benign or malignant, as it could have helped clarify other aspects of the study.

Some significant questions must be addressed to learn more about the utility of Ki-67. The first is the function of Ki-67 in the cell cycle. This important issue remains unresolved 14 years after the antibody was first described $[4,5]$. It has been proposed that $\mathrm{Ki}-67$ functions as a timer molecule in the cell cycle [8]. Because of the evolutionary conservation of Ki-67 antigen in many species and its expression in both benign and malignant cells, it has also been suggested that $\mathrm{Ki}-67$ has an important role in the regulation of cell proliferation, although some studies with cell hybrids have shown cell proliferation in the absence of Ki-67 antigen [8]. The recent cloning of the $\mathrm{Ki}-67$ gene has shown that it plays a pivotal role in maintaining cell proliferation [5], but its exact function remains unknown.

The second question is whether analysis of Ki-67 can be combined with that of other cell cycle proteins, such as p27 [9], topoisomerase II-alpha [10], and the many other cell cycle gene products that have recently been cloned to provide more of a definitive differentiation between benign and malignant tumors. This question will only be answered by future studies, which the paper by Farnebo et al. should stimulate. While we await future studies, we can agree with the conclusions of Farnebo et al. that Ki-67 can provide valuable information about which patients with parathyroid tumors should be followed more closely. 


\section{References}

1. DeLellis, R.A.: Atlas of Tumor Pathology. Tumors of the Parathyroid Gland. Third Series, Fasc. 6. Washington, DC, Armed Forces Institute of Pathology, 1993

2. Bondeson, L., Sandelin, K., Grimelius, L.: Histopathological variables and DNA cytometry in parathyroid carcinoma. Am. J. Surg. Pathol. 17:820, 1993

3. Rose, D.S., Maddox, P.H., Brown, D.C.: Which proliferation markers for routine immunohistology: a comparison of five antibodies. J. Clin. Pathol. 47:1010, 1994

4. Gerdes, J., Lemke, H., Baisch, H., Wacker, H.H., Schwab, V., Stein, $\mathrm{H}$.: Cell cycle analysis of a cell proliferation associated human nuclear antigen defined by the monoclonal antibody Ki-67. J. Immunol. 133:1710, 1984

5. Duchrow, M., Schluter, C., Wohlenberg, C., Fland, H.D., Gerdes, J.: Molecular characterization of the gene locus of the human cell proliferation-associated nuclear antigen defined by monoclonal antibody Ki-67. Cell Prolif. 29:1, 1996

6. Abbona, G.C., Papotti, M., Gasparri, G., Bussolati, G.: Proliferative activity in parathyroid tumors as detected by Ki-67 immunohistostaining. Hum. Pathol. 26:135, 1995

7. Lloyd, R.V., Carneyu, A.J., Ferreiro, J.A., Long, J., Thompson, G.B., van Heerden, J.A., Grant, C.S., Wollan, P.C.: Immunohistochemical analysis of the cell cycle associated antigens Ki-67 and retinoblastoma protein in parathyroid carcinomas and adenomas. Endocr. Pathol. 4:279, 1995

8. Brown, D.C., Gatter, K.C.: Monoclonal antibody Ki-67 its use in histopathology. Histopathology 17:489, 1996

9. Lloyd, R.V., Jin, L., Qian, X., Kulig, E.: Aberrant p27 ${ }^{\text {Kip1 }}$ expression in endocrine and other tumors. Am. J. Pathol. 150:401, 1997

10. Lynch, B.J., Guinee, D.G., Holden, J.A.: Human DNA topoisomerase II-alpha: a new marker of cell proliferation in invasive breast cancer. Hum. Pathol. 28:1180, 1997 